\title{
Section XVIII: Extraterritorial Operations Against Non-state Armed Groups
}

\section{Rule 153}

The right of self-defence applies in response to an armed attack by non-State armed groups.

\section{Commentary}

1. The exercise of the right of self-defence in response to an armed attack by non-State armed groups is demonstrated by the general practice and opinio juris of States in reaction to the events of September 11, 2001. This has been confirmed, inter alia, by Security Council resolutions (1368 and 1373) and by international organizations such as NATO.

\section{Rule 154}

A State may exercise its right of self-defence against non-State armed groups in a foreign State in response to an armed attack mounted by them from outside the victim State's territory, subject to the Charter of the United Nations.

\section{Commentary}

1. This Rule does not address the issue of domestic terrorism.

2. It might not be possible or necessary to distinguish between armed attacks launched by another State as such (whether it is carried out by de jure or de facto organs), on the one hand, and armed attacks carried out by non-State armed groups, on the other. The inherent right of self-defence, enshrined in Article 51 of the Charter of the United Nations, is not contingent on armed attack being attributable to another State.

3. If the foreign State knowingly provides shelter to the armed group, or otherwise connives with it, an armed attack carried out by the armed group it may bear responsibility for such actions. 
4. An armed attack by non-State armed groups may be launched from foreign territory, where there is no connivance by the territorial State notwithstanding the fact that the armed group has its base of operations within that territory. If the victim State exercises its right of self-defence, it will likely do so within the territory of the State in which such base of operation is situated. Nevertheless, the exercise of self-defence will be directed against the non-state armed groups and not against the foreign State itself.

\section{Rule 155}

Self-defence may be exercised in the circumstances referred to in Rule 154 without the consent of the incumbent territorial Government if the latter is unable or unwilling to take the action necessary to suppress armed attacks by a non-State armed group against the victim State.

\section{Commentary}

1. This mode of non-consensual self-defence is in conformity with the general practice of States and the Charter of the United Nations. It is sometimes called "extra-territorial law enforcement", which is permissible when a local Government is unable or unwilling to suppress armed attacks carried out by non-State armed groups against foreign States.

2. Admittedly, the scale of the use of force in self-defence against the "Islamic State" within Syria-by the U.S-led coalition, operating without the consent or invitation of the Syrian Government-is extraordinary.

3. As in all other instances of self-defence, the exercise of the right has to be carried out in accordance with the customary conditions of necessity, proportionality and immediacy.

\section{Rule 156}

The right of self-defence against non-State armed groups in the circumstances referred to in Rule 154 may be exercised either individually or collectively.

\section{Commentary}

1. The United States and other members of the international coalition have justified their military operations in Syria against the "Islamic State" on the ground of collective self-defence in response to an armed attack against Iraq.

2. In the meantime, the "Islamic State" has carried out numerous armed attacks against other countries. Most of the members of the large coalition that has been operating against the "Islamic State" have been acting in collective self-defence.

3. Some other members of the coalition fighting the "Islamic State" may have different rationales for their operations in Syria. 


\section{Rule 157}

The extra-territorial exercise of the right of self-defence against non-State armed groups does not per se bring into existence an international armed conflict.

\section{Commentary}

1. Broadly speaking, the armed conflict in Syria (beginning in 2011) constitutes a clear illustration of the application of this Rule.

2. The rationale is that the States conducting operations in Syria are engaged in fighting there either by invitation of the Syrian Government or-if operating without such invitation-they are confronting non-State armed groups in an exercise of the right of individual or collective self-defence against an armed attack.

3. The crux of the matter is that (broadly speaking) there have been no hostilities between States in Syria (in other words, the States belonging to the anti-"Islamic State" coalition and the Syrian Government have largely chosen not to engage one another with military force).

4. Despite the allegations of some, it should be stressed that the Syrian hostilities have not generated a new LOAC matrix by adding a third category to the existing dichotomy of international armed conflicts and non-international armed conflicts.

Open Access This chapter is licensed under the terms of the Creative Commons Attribution 4.0 International License (http://creativecommons.org/licenses/by/4.0/), which permits use, sharing, adaptation, distribution and reproduction in any medium or format, as long as you give appropriate credit to the original author(s) and the source, provide a link to the Creative Commons licence and indicate if changes were made.

The images or other third party material in this chapter are included in the chapter's Creative Commons licence, unless indicated otherwise in a credit line to the material. If material is not included in the chapter's Creative Commons licence and your intended use is not permitted by statutory regulation or exceeds the permitted use, you will need to obtain permission directly from the copyright holder.

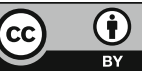

